\title{
Indi@logs
}

Vol 7 2020, pp 81-91, ISSN: 2339-8523

DOI https://doi.org/10.5565/rev/indialogs.153

\section{NAXALISM AND TRIBES IN INDIA}

AJEET JAISWAL

Pondicherry University rpgajeet@gmail.com

Received: 09-11-2019

Accepted: 22-11-2019

\begin{abstract}
India has the second largest concentration of tribal population in the world after the African continent. The Schedule Tribes (ST from now on) occupy isolate areas which are comprised of hilly terrain. These Schedule Tribes have a tradition of strongly resisting the infiltration of outsiders, and particularly foreign outsiders into their areas. History provides evidence of protracted struggles between the foreign invaders and the tribals when the former attempted to enter into their areas. In this light the present article aims to highlight the interpretational information related to Naxalism and tribes in India. Here, we present an overview of Naxalism, its genesis, the salient features of the 'Action Plan' of the Naxalite movement. We shall also discuss the so-called "Maoist Mayhem", and Naxalism in Tribal areas and its causes. We shall also discuss measures related to Naxalism and the tribal situation in general. As a conclusion, we shall argue that Naxalism is not a law and order problem but is, moreover, related to an imbalance in the dispensation of social and economic justice, with particular focus on land and mineral resources.
\end{abstract}

KEYWORDS: Naxalism, Tribes, PESA, Naxalite movement, Maoist Mayhem.

\section{RESUMEN El Naxalismo y las tribus de India}

India contiene la segunda mayor concentración de población tribal en el mundo después del continente africano. Tradicionalmente las llamadas "Scheduled Tribes" han ocupado áreas contiguas y aisladas, habitualmente terreno montañoso u ondulado, y han resistido con fiereza la infiltración de extraños en su territorio, sobre todo extranjeros. Existen evidencias históricas de un largo enfrentamiento entre los invasores extranjeros y las tribus cuando aquellos intentaron penetrar sus territorios. También se han dado rebeliones contra las autoridades dominantes. Este artículo se propone iluminar la información y las interpretaciones que existen sobre el Naxalismo y las tribus en India. Presenta una panorámica del Naxalismo, su génesis, y los rasgos principales del 'Plan de Acción' del movimiento, el caos maoísta, el Naxalismo en las áreas tribales, sus causas, el modo en que las tribus se han visto implicadas en el fuego cruzado, etc. Este artículo también revisa algunas importantes medidas en relación al Naxalismo y la situación de las tribus, para concluir que este movimiento no es un problema de ley y orden, sino que tiene su origen en desequilibrios en la dispensación de justicia social y económica, que implican problemas socio-económicos, en especial por cuanto refiere a la tierra y los recursos minerales.

Palabras Clave: Naxalismo, Tribus, PESA, Movimiento Naxalita, Caos Maoista. 


\section{Introduction}

India has the second largest concentration of tribal population in the world after the sum total of tribals on the African continent. The total ST population in India, as per 2011 Census, was 104281034 constituting about $8.6 \%$ of the total population of India. Of this, about $86 \%$ ST population is concentrated in the central belt covering nine states of M.P., Odisha, Chhatisgarh, Jharkhand, Gujarat, Maharastra, Rajasthan, A.P. and West Bengal. About 10\% of STs reside in the 8 North Eastern states of Assam, Arunachal Pradesh, Manipur, Meghalaya, Mizoram, Nagaland, Tripura and Sikkim and the remaining 4\% in the seven states of U.P., Uttarkhand, H.P., Goa, Bihar, Karnatak, Tamil Nadu and 6 union territories of Jammu and Kasmir, Laddak, Dadra and Nagar Haveli, Daman and Diu, Lakshadweep and Andaman and Nicobar Islands (Census of India, 2011; Jaiswal, 2012: 69; Jaiswal, 2019: 14).

The STs occupy isolated areas which are comprised of hilly terrain, and they strongly resisted the infiltration of outsiders in general and, particularly, that of foreign incursions into their areas. History provides evidence of protracted struggles between the foreign incursions and the tribals when the former attempted to enter into their areas. Several rebellions against the colonial authorities were registered, and the British, in order to seek peace with the tribals, had to designate tribal majority areas as non-regulatory areas and thus concede separate laws for the administration of these areas. These were specified as "excluded and partially excluded areas" and special laws were made for protecting the interest of the tribals (Majumdar, 1982: 8).

\section{Genesis of Naxalism}

Naxalism owes its name and origin to a small incident in Naxalbari village in the state of West Bengal in 1967 in which a small group of local tribals and other backward caste cultivators rose up against the feudal practices of exploitation, oppression and atrocities involving denial of their share in agricultural produce and the payment of fair wages by the upper caste landlords. On 25th May, 1967 the police opened up fire on protesting peasantsled by three men, Charu Mazumdar, Jungle Santhal and KanuSanyal (Loyd, 2015:84).Soon, this protest assumed the shape of a left wing people's movement which became known as the Naxalite movement, under the leadership of the aforementioned Charu Majumdar, KanuSanyal and Jungle Santhal. This movement gained control of almost all the entire rural areas of the State of West Bengal. They 
demanded socio-economic justice and the eradication of an oppressive feudal system. In many cases because of frustration born out of grievance, they resorted to violence to seek justice from the state agencies. The movement's main demands included land reforms, labour reforms, fair price for agro-forest produce, employment guarantee, and the elimination of exploitation in mining operations. This movement spread over to the adjoining state of Andhra Pradesh in 1968 and had its epicenter in North-Eastern districts of Adilabad, Srikakulam, and Visakhapatnam, including the Telangana region. The three leaders were arrested for their extremist activities and Mazumdar died in police custody in 1972. Santhal spent about a decade in jail and on died after his release in 1981. Only the diminutive Sanyal survived. After spending seven years in jail, he became involved in various forms of left politics, operating from his village near Naxalbari until he reportedly committed suicide on 23rd March, 2010 by hanging himself in his home at his native village at the age of 82 (Loyd, 2015: 84).

The movement had its ups and downs but it reached its climax in 1980 when the Communist Party of India (Marxist-Leninist). The People's War Group (PWG) was formed by Kondapalli Seetharamaiah an associate of Charu Mazumdar. Subsequently, PWG emerged as the most formidable Naxalite formation not only in Andhra Pradesh but also in adjoining states. This left wing extremist group is linked with economic injustice, unemployment, poverty, land reforms, lack of development and grievance frustration. Some studies have revealed that over 90 percent of the rural poor below the poverty line live in the 12 major states of Andhra Pradesh, Bihar, Karnataka, Madhya Pradesh, Chhattisgarh, Jharkhand, Maharashtra, Odisha, Rajasthan, Tamil Nadu, Uttar Pradesh and West Bengal. It is not a coincidence that the Naxalites are active in varying degrees in these states. The Naxalite pro-poor ideology has a strong gravitation for the youth among the student community (Loyd, 2015: 86; Bhagabati, 2001: 7).

The salient features of both the 'Action Plan' of the 'People's' War Group and the Naxalite movement are as follows (Mukherjee, 2007: 295):

\section{Salient features of the 'Action Plan' of the Naxalite movement}

- A redistributing of agriculture lands to the land-less and the excess land from big landlords

- Enforcing payment of minimum wages to farm labourers.

- Imposing taxes and penalties on corrupt contractors and officers. 
- Holding people's courts for the redressal of grievances and dispensation of quick justice to the aggrieved parties, free of cost.

- The running of a parallel government in the tribal areas for the administration of speedy justice.

- Collecting funds from contractors and the rich for meeting these running costs.

- The kidnapping of people for ransom so as to spread the message of this ideology.

- Attacking policemen as a counter measure to show their strength.

- Destroying government property to undermine state authority.

- Enforcing social code.

The People's War Group has been spearheading the movement of the oppressed and exploited tribals and poor peasants during the last four decades, and many disposed people feel that the Naxalites have achieved what the politicians have been promising year after year but have failed to deliver. Having tried the power of bullet, the Naxalite groups seem to be focusing gradually on human rights and civil liberties issues through the ballot box.

\section{Maoist Mayhem}

Naxal extremism, also called Maoist mayhem, has increased in recent years, as is illustrated by some instances in 2008, 2009 and 2010. Naxal attacks on police stations in Orissa's Nayagarh district on $15^{\text {th }}$ February, 2008 were deemed a wake-up call for India's security mandarins. The massacre of 35 police, (including a Superintendent of Police) in Rajnandgaon district on 12-13 July, 2009, or the Maoists guerilla attack on a CRPF camp in Kanker district by 76 paramilitary jawans on 6th April, 2010, are grim reminder of the security threat posed by Naxalism. The blunting of a civilian bus killing 44 passengers in Chhattisgarh is also a serious case of concern (Verma, 2018: 238).

With every passing day, the Maoist guerrillas seem to be tightening their grip on many parts of India, claiming about 600 lives per year. The year wise position of casualties of Naxal attacks since 2005 to 2010 and the position of deaths related to violence since 1996 to 2018 is provided in table 1 and 2 below. 
Table 1. Year wise position of Casualties in Naxal attacks since 2005 to 2010.

\begin{tabular}{|l|l|l|l|l|}
\hline Year & Security Personnel Killed & Civilians Killed & Maoist attacks & Maoist Killed \\
\hline 2005 & 153 & 524 & 1608 & NA \\
\hline 2006 & 157 & 521 & 1509 & 274 \\
\hline 2007 & 236 & 460 & 1565 & 141 \\
\hline 2008 & 231 & 660 & 1591 & 199 \\
\hline 2009 & 317 & 591 & 1130 & 217 \\
\hline 2010 & 285 & 713 & NA & 171 \\
\hline 2011 & 142 & 447 & NA & NA \\
\hline
\end{tabular}

Source: Verma, (2018), Indian Tribes: Through the Ages. (232).

Table 2. Year wise position of Deaths related to violence since 1996 to 2018

\begin{tabular}{|l|l|l|l|l|}
\hline Period & Civilians & Security forces & Insurgents & Total per period \\
\hline 1996 & N/A & N/A & N/A & 156 \\
\hline 1997 & 202 & 44 & 102 & 348 \\
\hline 1998 & 118 & 42 & 110 & 270 \\
\hline 1999 & 502 & 96 & 261 & 859 \\
\hline 2000 & 452 & 98 & 254 & 804 \\
\hline 2001 & 439 & 125 & 182 & 746 \\
\hline 2002 & 382 & 100 & 141 & 623 \\
\hline 2003 & 410 & 105 & 216 & 731 \\
\hline 2004 & 466 & 100 & 87 & 653 \\
\hline 2005 & $281-524$ & $150-153$ & $225-286$ & $717-902$ \\
\hline 2006 & $266-521$ & $128-157$ & $274-343$ & $737-952$ \\
\hline 2007 & $240-460$ & $218-236$ & $141-192$ & $650-837$ \\
\hline 2008 & $220-490$ & $214-231$ & $199-214$ & $648-920$ \\
\hline 2009 & $391-591$ & $312-317$ & $220-294$ & $997-1,128$ \\
\hline 2010 & $626-720$ & $277-285$ & $172-277$ & $1,177-1,180$ \\
\hline
\end{tabular}




\begin{tabular}{|l|l|l|l|l|}
\hline 2011 & $275-469$ & $128-142$ & $99-199$ & $602-710$ \\
\hline 2012 & $146-301$ & $104-114$ & $74-117$ & $367-489$ \\
\hline 2013 & $159-282$ & $111-115$ & $100-151$ & $421-497$ \\
\hline 2014 & $128-222$ & $87-88$ & $63-99$ & $314-373$ \\
\hline 2015 & $93-171$ & $57-58$ & $89-101$ & $251-318$ \\
\hline 2016 & $123-213$ & $65-66$ & $222-244$ & $433-500$ \\
\hline 2017 & 109 & 74 & 150 & 333 \\
\hline 2018 & 7 & 12 & 21 & 40 \\
\hline Total & $6,035-8,051$ & $2,277-3,440$ & $3,402-4,041$ & $12,877-14,369$ \\
\hline
\end{tabular}

Source: South Asian Terrorism Portal, 2018.

Naxalism is considered the single biggest threat to India's security. Many Indian states have been trying to fight the Maoists for some time, but with little success. States are required to pool their resources and crush the leftist rebellion once for all. The factors which gave rise to Naxalism in the country in late sixties are, in any cases, are also very much present today in an acute and aggravated form. The erosion of faith in the political processes, the grinding poverty of a large mass of humanity, economic disparities, mounting unemployment, tribal unrest, aggravating social tensions, and the failure of the administration to fulfill the rising expectations of the people are take their toll and are leading to a highly surcharged situation (Bijoy, 2010: 21).

\section{Naxalism in Tribal Areas}

In India about 80 million tribals are still considered to be the most vulnerable and poorest of the poor. A large section of the tribal population living below poverty line are victim of hunger and malnutrition (Mehta, 2004:17). Tribals are dying of hunger which is caused by food insecurity, and poverty, in turn causes death by starvation which creates a kind of terror amongst this population. Hunger has thus been used as tool of terror against the tribals so as to keep them in the state of total subjugation and inner colonization.

\section{Causes of Naxalism}


The root causes of Naxalism among the tribals are directly linked to social, economic and political grievances which include: deprivation, degradation, exploitation, poverty, unemployment, illiteracy, oppression and historical wrongs. Despite the constitutional safeguards with twin objectives of empowerment and development of tribals for their integration into the mainstream of the nation, they have been denied social economic, political justice and human rights. More than $50 \%$ of them are illiterate and live below poverty line under inhuman conditions. They are arbitrarily deprived of their land rights and rights pertaining to forest areas. Their lands are not safe even in the scheduled areas, and they are facing indiscriminate displacement without an adequate rehabilitation package. Furthermore, they are exploited by money lenders and also by the government agencies engaged in their so-called welfare. Democracy has little meaning for the tribals as, amongst other things, they are being used as vote banks for democracy without any participation in the process of decision making on tribal affairs (Singh, 1999: 101; Verma, 2018: 239).

Tribals are helpless victims of bad governance and exploitation, and the dwindling resource base of the tribal people can be quantified in the shape of loss of land, restriction of access to forest produce and a lack of opportunities for reasonable wage employment. Consequently, developmental inputs for the benefit of these people have had little impact. Significantly, development processes have interfered in many cases with traditional tribal institutional structures and this has produced many negative results. These were contributory factors for simmering unrest in most of the tribal areas (Singh, 1999:101).

It was in the background of utter grievance frustration of the tribals arising out of their exploitation and oppression which led them to their taking arms in several areas to fight for their rights under the patronage of Naxalites. In fact, over the years, tribal insurgency has become the predominant strand of the Naxalite and people's war group movement. The combination of socio-economic and political factors has led to a resurgence of left-wing extremism and the Naxalite movement in India. The Naxalite ideology seeks to cut across the barriers of caste, religion and region and unite people on broader economic issues (Hooja, 2004: 16; Verma, 2018: 256). 


\section{Tribals caught in the crossfire}

According to tribal people Land, water, minerals, poverty and guns are all connected for their existence. In India's heartland, there are tribal villages where people have not seen a doctor, a teacher, tap water or electricity and, furthermore, they live in the middle of dense forests, sharing space with dangerous animals. Whilst occupying fertile land, hunger still haunts them, and in Chhattisgarh, the state with the highest tribal population in the country, even basic human needs and civic amenities like drinking water, food, health, electricity and education facilities are lacking. Even the areas in the grip of violence are beyond the reach of the police forces. The people are famished and forced to live a sub-human life (Louis, 2008:17).

It is the same story in the tribal areas of other states like Jharkhand, Odisha, Madhya Pradesh, and Andhra Pradesh. More than $50 \%$ of the tribal villages are without roads, electricity, potable water and health centers and education facilities. No wonder when they hear about the mining companies coming and taking away their mineral wealth, they are enraged. They want their land back. They want their forests intact and they don't want others to exploit their minerals. When they see everything slipping away from their hands they turn to guns. Now the tribals are simmering with anger. When the Maoists walk into a village and talk of revolution, people listen. The Tribes realize that they were never given a chance to live with dignity, yet they are caught in a deadly crossfire between the rebels who claim that they are waging a war on their behalf and the state that says it is trying to protect them from the Maoists' mindless violence (Louis, 2008:15).

\section{Suggestive measures:}

1. Decentralization of authority to the Panchayati Raj Institution (PRI) by implementing the provisions of Part IX and IXA of the Constitution Provisions of Panchayats Extension to Scheduled Areas (PESA) for grass root democracy and good governance at village level. There should be devolution of a) functions, b) functionaries and c) finances. District Planning Committees should be formed and separate budgets be allocated to PRIS for implementation of the schemes of development (Ministry of Tribal Affair, 2015: 33). 
2. The Scheduled Tribes and Other Traditional Forest Dwellers (Recognition of Forest Rights) Act, 2006 and Rule 2007 should be implemented in letter and spirit at the earliest possible date to undo the historical injustice to tribals (Ministry of Tribal Affair, 2015: $34)$.

3. Protection of land rights of tribals in terms of the Supreme Court judgment in Ramu Reddy case (AIR 1988 SC) and protection of mining rights of tribals in terms of Samta decision (AIR 1997 SC) should be ensured.

4. A Central Tribal Advisory Council should also be formed under the chairmanship of the Prime Minister for advising on policy planning and development matters.

5. There should be a separate quantification of funds by the Central Government and Nitti Aayog under separate budget head for tribal development.

6. The Ministry of Tribal Affairs should be notified as the nodal administrative Ministry for monitoring of funds and implementation of programmes and schemes sponsored by the government of India.

7. A comprehensive policy of tribal empowerment should be formulated by the Ministry of Tribal Affairs, keeping in view the constitutional guarantees and policy guidelines, called the "Tribal Pachsheel", spelt out by Pt. Jawaharlal Nehru, the first Prime Minister of India, which placed reliance on tribals for administration of their affairs

\section{Conclusion}

Naxalism is not a law and order problem but it is basically related to the imbalance in dispensation of social and economic justice, involving socio-economic issues, particularly land and mineral resources. There should be effective devolution of authority to the Panchayati Raj Institutions for people's participation within the administration of justice and management of their affairs at the root level. Sincere efforts of the government in this direction will go a long way in containing Naxalism. 


\section{WORKS CiTED}

BHAGABATI A. C. (2001). Emergent Tribal Identity in North-East India. New Delhi: Concept Publishing Company, 3-9.

BIJOY, C, R. (2010). India and the Rights of Indigenous People, Asia Indigenous People Pact, Thailand, The World Bank, Poverty and Social Exclusion in India, Oxford University Press, New Delhi.

CENSUS OF INDIA. (2011). Ministry of Home Affairs. Publication Division, New Delhi. 2013, 11-47.

GOSWAMI, N. (2014). Indian National Security and Counter-Insurgency: The Use of Force vs Non-violent Response. Routledge.

HOOJA, M. (2004). Policies and Strategies for Tribal Development: Focus on the Central Tribal Belt. New Delhi: Rawat Publications.

JAISWAL, A. (2012). "Tribal Development in North Eastern Part of India: Reality and Constrains". Social Work Chronicle, 1 (2), 68-81.

JAISWAL, A. (2019). “Tribes in India: India's Overall Demographic Scene and Demographic Features in Tribal Societies". Anthropology and Ethnology Open Access Journal, 2(3), 116.

LOUIS, P. (2008). Rights of Scheduled Tribes of India. MANAK Publication Pvt. Ltd, New Delhi.

LOYD, ANTHONY (2015). "India's Insurgency". National Geographic (April): 82-94. Retrieved 13 March 2018 https://www.nationalgeographic.com/magazine/2015/04/indiacoal-conflict-minerals-maoist-insurgency/

MAJUMDAR D. N. (1982). "An Appraisal of the Tribal Situation in North East India”, In Pankaj Thakur (ed.), India's North East. Tinsukia: Prakash Publishing House, 7-15.

MUKHERJEE, A. (2007). Maoist "Spring Thunder": the Naxalite Movement 1967-1972. K.P. Bagchi \& Co., Calcutta. 295.

MEHTA P. C. (2004). Ethnographic Atlas of Indian Tribes. New Delhi: Discovery Publishing House.

SINGH, P. (1999). The Naxalite Movement in India. New Delhi: Rupa \& Co., 1999.

MINISTRY OF TRIBAL AFFAIRS. (2015). Annual Report 2015-16. New Delhi: Government of India. 
VERMA, R.C. (2018). Indian Tribes: Through the Ages. Publication Division, Ministry of Information and Broadcasting, Government of India.

AJeet JAISWAL is an Assistant Professor of Anthropology at Department of Anthropology, Pondicherry University, Puducherry, India. He is a renowned author of eight books, written 65 papers and 40 units or modules, published in different national and international reputed peer reviewed research journals. 